\title{
The Development of Innovative Media Education Styles in the Era of Information and Communication Technologies
}

\author{
Mariya Butyrina $^{1}$, Tetiana Hyrina, ${ }^{2}$, Inna Penchuk ${ }^{3}$, Iryna Bondarenko ${ }^{4}$, Ganna Skurtul ${ }^{5} \&$ Nataliia Tiapkina $^{2}$ \\ ${ }^{1}$ Department of Mass and International Communication, Oles Honchar Dnipro National University, Dnipro, Ukraine \\ ${ }^{2}$ Department of Ukrainian Philology and Culture, University of the State Fiscal Service of Ukraine, Irpin, Ukraine \\ ${ }^{3}$ Department of Journalism and Ukrainian Philology, Classic Private University, Ukraine \\ ${ }^{4}$ Department of Social Communications and Information Activities, Zaporizhzhia National University, Zaporizhzhia, \\ Ukraine \\ ${ }^{5}$ Department of Journalism, National University “Zaporizhzhia Polytechnic”, Zaporizhzhia, Ukraine \\ ${ }^{6}$ Department of Publishing and Editing, Zaporizhzhia National University, Zaporizhzhia, Ukraine \\ *Correspondence: Department of Ukrainian Philology and Culture, University of the State Fiscal Service of Ukraine, \\ 31, University street, Irpin, 08201, Ukraine
}

Received: December 9, 2021

Accepted: January 6, 2022 Online Published: January 17, 2022

doi:10.5430/jct.v11n $1 \mathrm{p} 195$

URL: https://doi.org/10.5430/jct.v11n1p195

\begin{abstract}
The new era of the 21 st century is characterized by the rapid pace of digitalization of society and the development of information and communication technologies (ICTs). ICTs are transforming the basics of educational activities from the physical environment to the virtual one. There is a similarity between technology and media in content and strategic context. The media actively influence the public opinion, and information and communication technologies are used to increase the impact on academic performance. Therefore, there is a need for a critical analysis of information reality in order to develop the competence in future generation. The article provides the study of the process of development of innovative media education styles, which are effective in educational activities for the formation of a competent future generation capable of critical analysis of the information. The study of the formation of innovative media education styles was based on the Synyavsky's communicative and organizational skills measurement methods in order to diagnose the main aspects of educational activities in the innovative context, Milman's personal motivation technique, survey to determine the competency criterion of media education. A pedagogical experiment was conducted as part of the study. The results of the study became the ground for determining the content of innovative media education styles as an alternative to modern forms of education. Innovative media education styles are formed due to the influence of ICTs on educational activities. The obtained data were processed in SPSS 18.0.1.
\end{abstract}

Keywords: competence, values, self-fulfilment, quality of education, innovations, media education

\section{Introduction}

The current social development is in the process of globalization and integration. Factors of active development of mankind are economic and political, because the relevant features are manifestations of human well-being in the process of socialization. To succeed in socio-economic development, it is necessary to increase the level of education, because education is an important factor in shaping a person capable of self-fulfilment in a society.

The period of modern history is characterized by the development of information technology, its penetration into almost all spheres of public life (Noonan, 2017). This trend is reflected in determining the approaches to the establishment or reformation of the main social institutions, which are the result of the activities and needs of citizens, encourages the reform of the basics of educational activities. There is a need for the development of innovative media education styles among students (Katz, 2013). However, the new generation plays the main role in the formation of post-industrial society, who will have much better ICT skills than the previous generation (Loreman et al., 2016). Therefore, the educational process is a manifestation of innovative styles in the context of media 
education, which is implemented in the development of information and communication technologies.

Education is an important phenomenon in public life, an advance in evolutionary and civilizational cultural progress, while being a consequence of civilizational achievements of man and at the same time. The 21 st century has become a challenge for society, because the achievements of mankind have achieved high results, which are far ahead of human demand (Bessarab et al., 2021a; 2021b). The transformation of digital technologies into the educational environment contributes to the formation of new approaches to the educational process, which is a consequence of informatization and media support. Therefore, the educational process is important for citizens and needs constant reform and modernization in the context of shaping an innovative post-industrial world.

Education and science are the phenomena indicating the civilization-evolutionary process and, at the same time, are criteria for creating new foundations in the development of individuals and society as a whole (Gray, 2008). Recent trends indicate the continuous progress of man, which became the basis for the formation of information and communication space of the new generation. On the one hand - innovative digital technologies — "know-how", on the other - the result of previous human experience (Katz, 2013).

Information and communication technologies have determined the vector of evolution of humanity in the new era. In different spheres of human activity, the way and approach to achieve the result is changing, in particular, there is a digital transformation of human activity. One of the important tools for shaping the students' worldview in the post-industrial innovation society is media education. Therefore, the topic of the research is "The Development of Innovative Media Education Styles in the Era of Information and Communication Technologies".

That is, in the period of informatization and introduction of innovative approaches it is necessary to modernize the main components of educational activities, change the format of educational activities from regular offline learning to online one, which more effectively promotes student competence and value orientations (Abulalrub \& Stensaker, 2018). Education as a factor in an effective state must be a valuable investment in human capital.

Researchers consider information and communication technologies as one of the means to change the perception of education, including the transition to a virtual educational environment and the formation of a new media education style that combines media technology in the context of online learning and traditional approaches.

Thus, analysing the main approaches of scientists to educational activities, we can understand how the factor of media education affects the formation of a new style of learning. Media education forms professional competencies and basic value orientations in a person, which ensures the competitive existence of mankind in the context of globalization and integration of various spectrums of public life. Media education is a theoretical acquisition of knowledge, their practical application with the use of information and communication technologies in the context of pedagogical education, that is teaching students. Media education involves the development of different types of media: graphic, print, visual, etc. Media education as a factor of mass communication provides an opportunity to achieve educational goals in the context of the use of social networks, the possibility of using the media to acquire new knowledge (Bauman, 2013). However, the effectiveness of media education is possible provided the knowledge of analysis, critical thinking and mastery of media texts; identification of sources of media texts, their political, social and economic context; interpretation of media texts as the value of media education in the context of virtual distance learning; transforming media texts as own educational product in the context of media education.

The aim of the article is to analyse and experimentally study the effectiveness of innovative media education styles in the era of information and communication technologies as prospects for successful social development. The aim involved the following objectives:

1) Investigate the essence of media education as a basis for the formation of innovative learning styles;

2) Analyse the main theoretical and methodological approaches to media education;

3) Experimentally study innovative styles in the era of information and communication technologies as a basis for the formation of the integration of virtual and physical educational environment for students.

\section{Literature Review}

To determine the features of media education in the context of learning, it is necessary to analyse the conclusions of scientists. Education is, first of all, a process of communication. Mashovets (2017) argues that the modern educational process is shaped by the digital paradigm and leads to techno-media convergence, an important environment in itself, which is interpreted from the physical state to the virtual.

There is no doubt that a revolution has taken place in our lives, because digital media has penetrated our lives. The 
revolution went much further than the theoretical limits presented by such authors as Castells (1996) and Negroponte et al. (1997), because they described the communication revolution as a phenomenon affecting all dimensions of human activity.

All this, of course, has the consequences of unusual transcendence in education and educational research. Today, everyone must learn about ICT within the parameters of media education, in the classical sense of the term. Greenhow, Sonnevend and Agur (2016) believe that the use of ICT in education is undoubtedly the best (and perhaps the only) way to fully understand the role and importance of digital technologies in society and the impact they have through information. They are a very powerful means of communication. On the other hand, theoretical postulates and practical experience in the context of media education need to be adapted to the new reality. Media education has a decisive influence on the teaching style, making teachers experts not only in their knowledge and didactic use but, above all, in creating a critical and constructive attitude of students to reality.

ICTs are not only management tools, but effective means. Therefore, media education is more necessary than ever it should be the basis of any scientific research. Classical contributions of such authors as Greenhow, Sonnevend and Agur (2016) can serve as a methodological and structural reference for the current study of ICT, in relation to their use in education. Updating the traditional design is necessary, he notes.

So, due to its experience and results media education should guide all research in the field of education. It is clearly focused on pedagogy, based on the use of media in educational practice, and is not reduced to a purely theoretical construction, as Galán (2016) noted. Practical experience in modern media realities is essential. There are many studies that develop the experience of working with computer programmes in the context of the formation of media education.

\section{Materials and Methods}

A study was conducted to determine the effectiveness of innovative styles in the context of media education. The research procedure was carried out in three stages during April-October 2021. The programme of the summative stage of the study is presented in Table 1.

Table 1. The Programme of the Ascertaining Stage of Experimental Research

\begin{tabular}{|c|c|}
\hline Name of the stage & Context of the experimental work \\
\hline \multirow[t]{3}{*}{ Preparatory } & Synthesis and analysis of the theoretical and methodological background of the study; \\
\hline & $\begin{array}{l}\text { Definition of basic concepts on the topic of introducing media education as the formation of } \\
\text { innovative styles in the era of information and communication technologies; }\end{array}$ \\
\hline & Selection of main research methods. \\
\hline \multirow[t]{2}{*}{ Summative } & Determining the state of educational activities of students in terms of innovative education; \\
\hline & $\begin{array}{l}\text { Establishing the state of motivation and communicativeness of students as a manifestation of } \\
\text { media education in the era of information and communication technologies }\end{array}$ \\
\hline Resulting & $\begin{array}{l}\text { Generalization of the results of the summative stage of the experiment, development of the } \\
\text { concept, content, forms and methods, models and technologies, recommendations for the } \\
\text { formative stage of the experiment, namely the selection of innovative media education styles. }\end{array}$ \\
\hline
\end{tabular}

The study involved in-depth interview to determine expert assessment in order to control the main aspects of media education as a manifestation of innovative learning styles, and a survey through the COS method was also conducted (Synyavsky \& Fedoryshyn, 2016) to determine the level of communicative and organizational abilities of students in the context of the introduction of media education. Milman's (2017) personal motivation technique was also applied to determine the impact of media education on the formation of the students' motivational aspect of learning. Diagnostics during the ascertaining stage of the study was implemented on the basis of the Milman's personal motivation technique. This technique involves the use of a questionnaire consisting of 65 statements, with each respondent being evaluated on a four-point scale. In the context of the study, the technique was analysed as a criterion for the formation of competence in the motivational manifestation.

A pedagogical experiment was conducted in order to effectively define innovative media education styles, which consisted of the summative, formative and control stages and became the basis for determining the results of the 
introduction of media education. The survey, the experiment and the diagnostics were the tools of research. Questionnaires were used to determine students' assessment of their own educational activities.

The pedagogical experiment consisted of three stages:

Stage 1 - summative, which was to ascertain and generalize the level of students' competence in the context of educational activities.

Stage 2 - formative, which was to develop recommendations for media education as a manifestation of innovative styles in terms of ICT education.

Stage 3 - control, which was to test and implement recommendations for media education and determining the most optimal styles of educational activities.

The summative stage is the identification of the current state of professional training of students for the further implementation of recommendations for the formation of innovative media education styles.

The preparatory stage of the summative part of the experiment involved content analysis of technologies and teaching methods, as well as the levels of students' competence.

Various methods were used in order to fulfil the relevant objectives:

1) questionnaire survey through Syniavskyi's COS method (Synyavsky \& Fedoryshyn, 2016) and the Milman's (2017) personal motivation technique, expert evaluation;

2) quantitative (mathematical and statistical methods) and qualitative (analysis, synthesis, comparison) methods of experimental data processing; 3 ) interpretive methods (determination of patterns, formulation of results and drawing conclusions).

The sample was formed from among the students majoring in Psychological Counselling of the National Pedagogical Dragomanov University, Faculty of Pedagogy and Psychology. The summative experiment was conducted with 200 2nd-year students divided into the experimental (100 students) and control groups (100 students). The method of research of special competence of future teachers also provided the analysis of the level of motivational, cognitive, personal, behavioural components in the context of media education.

Based on the aim of the study, we identified the main criteria and levels of competence of students in the context of media education (Table 2).

Table 2. Methods of Research of Empirical Indicators to Determine the Components and Levels of Motivation, Communication in Students in the Context of Media Education

\begin{tabular}{|c|c|c|c|}
\hline Component & Criterion & Indicators & Methods \\
\hline Motivational & $\begin{array}{l}\text { Learning motivation } \\
\text { in the context of } \\
\text { media education }\end{array}$ & $\begin{array}{l}\text { Interest in developing competence in their major in } \\
\text { the context of media education }\end{array}$ & $\begin{array}{l}\text { Milman's (2017) } \\
\text { personal } \\
\text { motivation } \\
\text { technique }\end{array}$ \\
\hline $\begin{array}{l}\text { Communicative } \\
\text { and organizational } \\
\text { skills }\end{array}$ & $\begin{array}{l}\text { Communicative and } \\
\text { organizational skills }\end{array}$ & $\begin{array}{l}\text { Communicative and organizational skills in the } \\
\text { context of media education as a manifestation of the } \\
\text { results of information and communication } \\
\text { technologies }\end{array}$ & $\begin{array}{l}\text { Synyavsky and } \\
\text { Fedoryshyn } \\
\text { (2016) COS test }\end{array}$ \\
\hline $\begin{array}{l}\text { Competence-base } \\
\text { d }\end{array}$ & $\begin{array}{l}\text { Skills for the } \\
\text { professional activities } \\
\text { as the effectiveness of } \\
\text { media education }\end{array}$ & $\begin{array}{l}\text { Self-assessment of professional competence } \\
\text { Self-assessment of the level of skills: diagnostic, } \\
\text { research, self-organization, organization of others, } \\
\text { understanding one's own motives, understanding the } \\
\text { motives of others, motivating oneself to action, } \\
\text { motivating others, self-control, control of others, } \\
\text { consulting, public speaking skills }\end{array}$ & Author's test \\
\hline
\end{tabular}

According to the data shown in Table 2, namely the empirical definition of components, indicators of students' motivation and communication, we determined the levels of students' competence in accordance with their major based on the introduction of media education. 
High level is represented on the basis of skills and abilities to critically analyse media sources in the context of the educational process, communicative and organizational skills when using media resources, high motivation during online classes or using social networks as a means to implement educational activities (Nychkalo, 2008).

The medium level is characterized by the communicative and organizational tendencies to participate in conducting classes in the context of media education, but the lack of initiative in organizing such classes, that is low motivation.

Low level: communication skills are insufficient. Insufficient knowledge and skills in the field of professional specialization, low motivation to study.

Based on the methodology, it was found that students with a medium level of motivation dominate $-44 \%$. There were no indicators of low motivation, and the criteria for creative potential were quite high. The medium and above medium indicators dominate. Based on the survey, a diagram was made of the criterion indicator of the motivational sphere of personality as a manifestation of student competence in the context of media education (Figure 1).

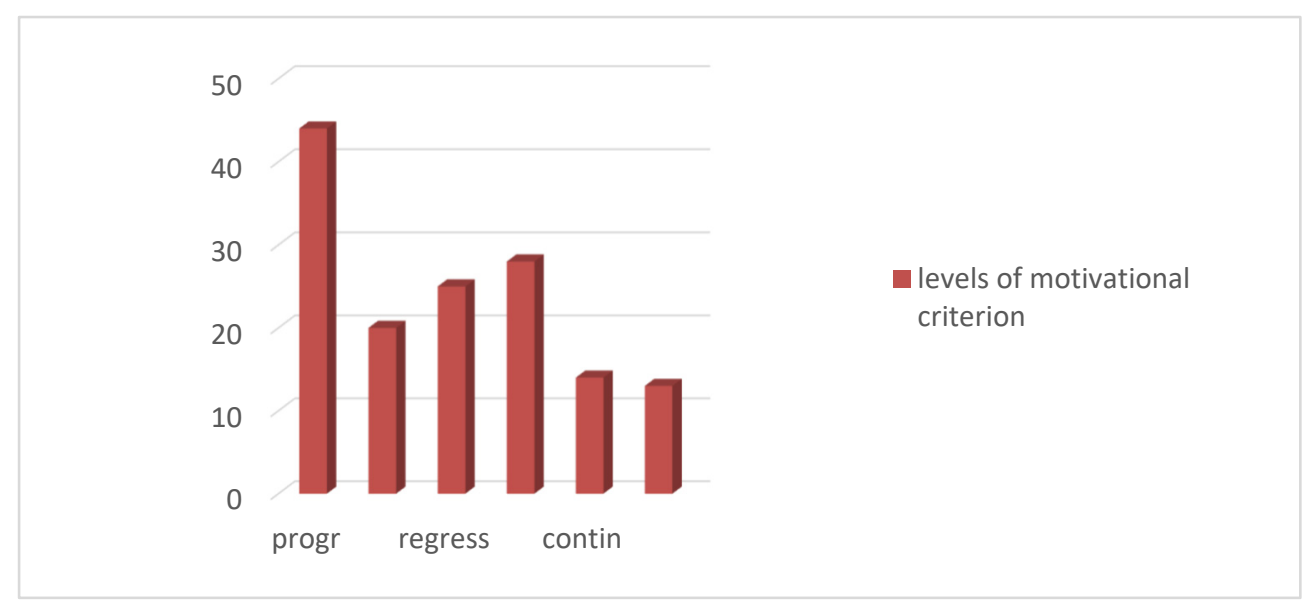

Figure 1. Levels of the Motivational Criterion

Next, the students' competence in terms of communicative and organizational skills in the context of conducting a survey through the appropriate methodology was determined. According to the survey, it is clear that students have medium indicators of communicative and organizational skills in the process of media education, as they do not yet fully master the peculiarities of their specialization. However, media education contributes to the development of the student's personality, who is constantly in search of information, critically comprehends and represents it, which characterizes the context of the use of media education. Synyavsky and Fedoryshyn (2016) COS test (communicative and organizational skills) was used to determine the level of competence of future specialists.

The analysis of indicators is the result of statistical and interpretive methods: quantitative - mathematical, statistical methods (charts, tables, testing the significance of statistical differences, etc.), and qualitative (analysis and synthesis of data, their arrangement and comparison, determination of patterns, formulation of results and drawing conclusions).

The levels of organizational and communicative skills were determined based on empirical data (Figure 2).

Empirical data on the criteria of communicative and organizational tendencies become the basis for the assertion that students have more developed communicative competencies, because they analyse and represent information obtained from media resources more often. Organizational aspects of media education are mainly formed through the presentation of teachers.

So, the summative stage of the study becomes the basis for determining the formative stage, in particular, recommendations for selecting innovative media education styles with the effective use of information and communication technologies (Vdovych \& Palka, 2013). The summative stage shows the state and levels of developed competencies on the basis of communicative-organizational and motivational criteria of the student's personality in the process of media education (Gygli et al., 2019). The results showed that $23.2 \%$ of respondents have a high level of the motivational and value component of readiness for instilling responsibility, $32.3 \%$ have a sufficient level and $44.5 \%$ have a low level. 


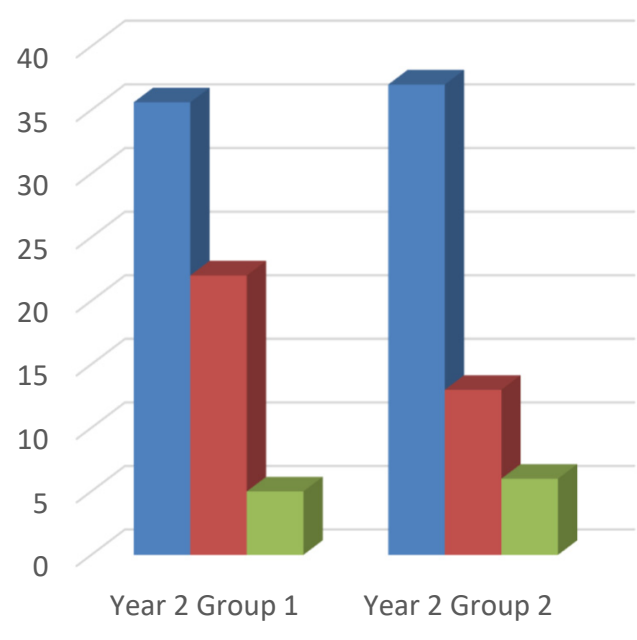

communicati ve skills

organizationa I skills

- low levels of C\&O skills

Figure 2. Indicators of the Communicative and Organizational Skills Measured Through the Synyavsky and Fedoryshyn (2016) COS Test

One of the indicators of student learning in the context of media education is competence (Gardner, 1983). The criterion of manifestations of critical thinking in terms of the analysis of media sources, responsibility, skills of content analysis of media resources is determined using the method of expert evaluation. Competent judges were teachers and supervisors of the institutions and organizations where students underwent pedagogical externship. The representation of the competence approach to identifying the level of success in the context of media education is shown in the author's questionnaire "Media resources - a source of knowledge and skills" (Appendix A) (Giddens, 1991). There were $2.5 \%$ of students who had a personal component at a high level, $39.2 \%$ - at a sufficient level, and $58.3 \%$ - at a low level.

Of all students surveyed, only $8.1 \%$ had a high level of all readiness components, a sufficient level was found in $34.2 \%$, while $57.7 \%$ of students lacked this complex personal formation at all (Figure 3 ).

Based on the indicators of the summative stage of the experiment, we established the main criteria for media education as an aspect of innovation, which should be distinguished by certain styles, in order to more effectively build students' competence in the era of information and communication technologies (Nelson, Courier \& Joseph, 2011). Therefore, the next step was to conduct a formative experiment to determine the appropriate styles.

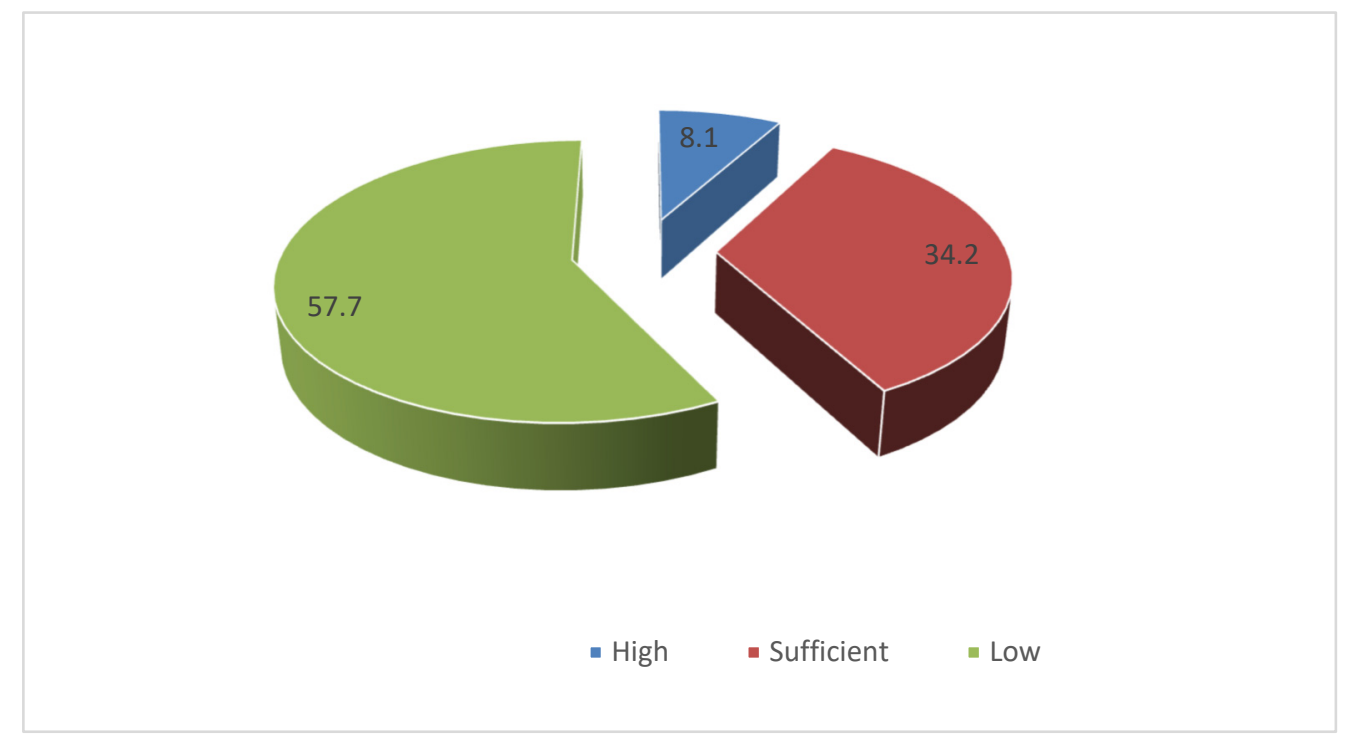

Figure 3. Levels of the Students' Competence Approach to Media Education 


\section{Research Results}

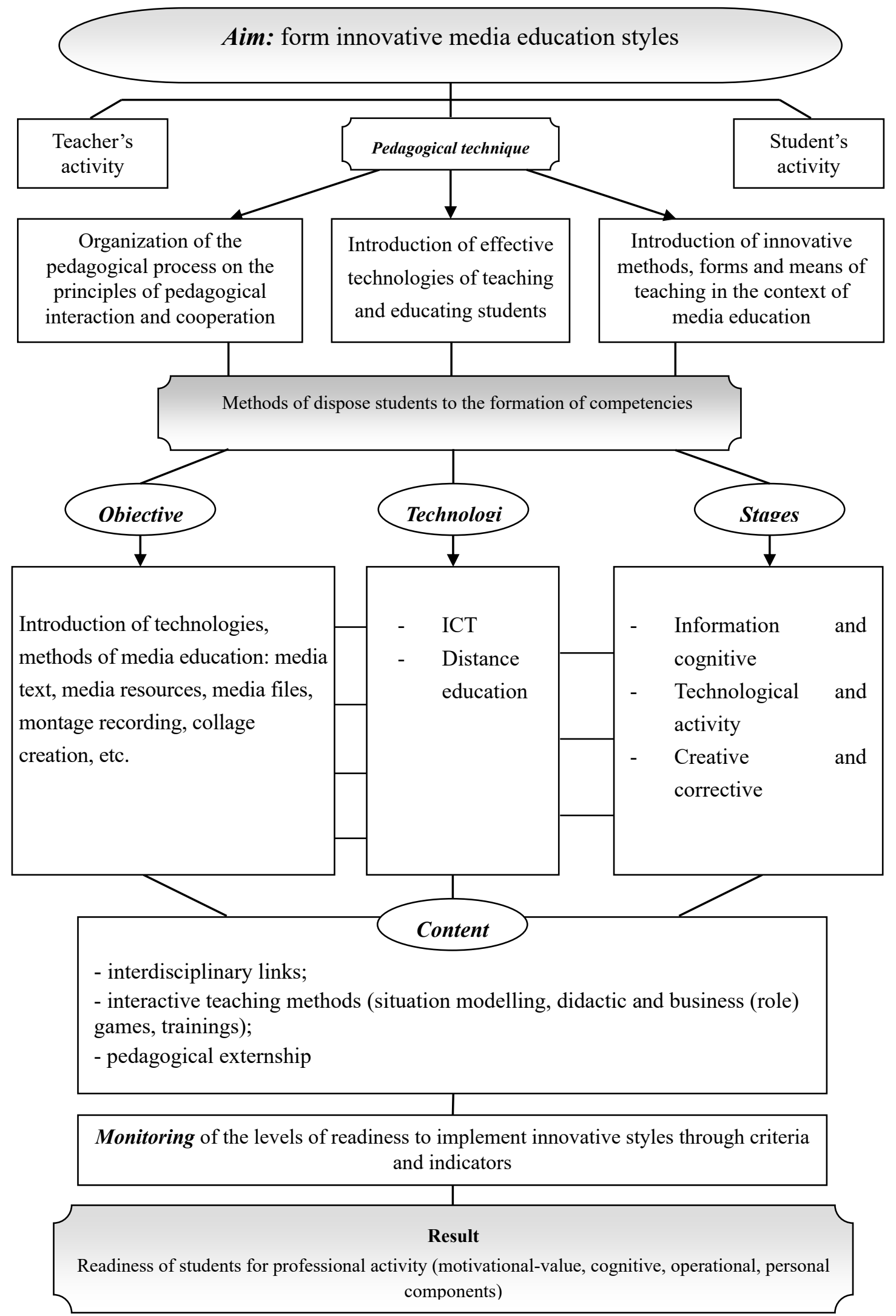

Figure 4. Model of Making Students Ready to Define Innovative Styles of Media Education (developed by the authors) 
The formative experiment was conducted only with students of the experimental group. The goals of the formative experiment are to identify and develop recommendations for the introduction of media education in the educational process of students and the definition of innovative learning styles, combining distance education with online education. Based on the appropriate indicators, the main approaches to media education were formed, which is the unity of pedagogical conditions, tasks, technologies, stages, content, monitoring and the result of media educational activities of students in higher educational institutions (Figure 4).

The next was a control stage of the experiment, which identified the main approaches to the introduction of media education in the era of information and communication technologies.

So, the results of the control study showed the following level of students' readiness (Figure 5):

1) Motivational;

2) Organizational and communicative;

3) Competence-based.

The results of the summative stage of the experiment showed no high level of communicative, motivational and competence level in 2nd-year students. These levels were close to $28 \%$ before the experiment, and reached about $50 \%$ after the experiment.

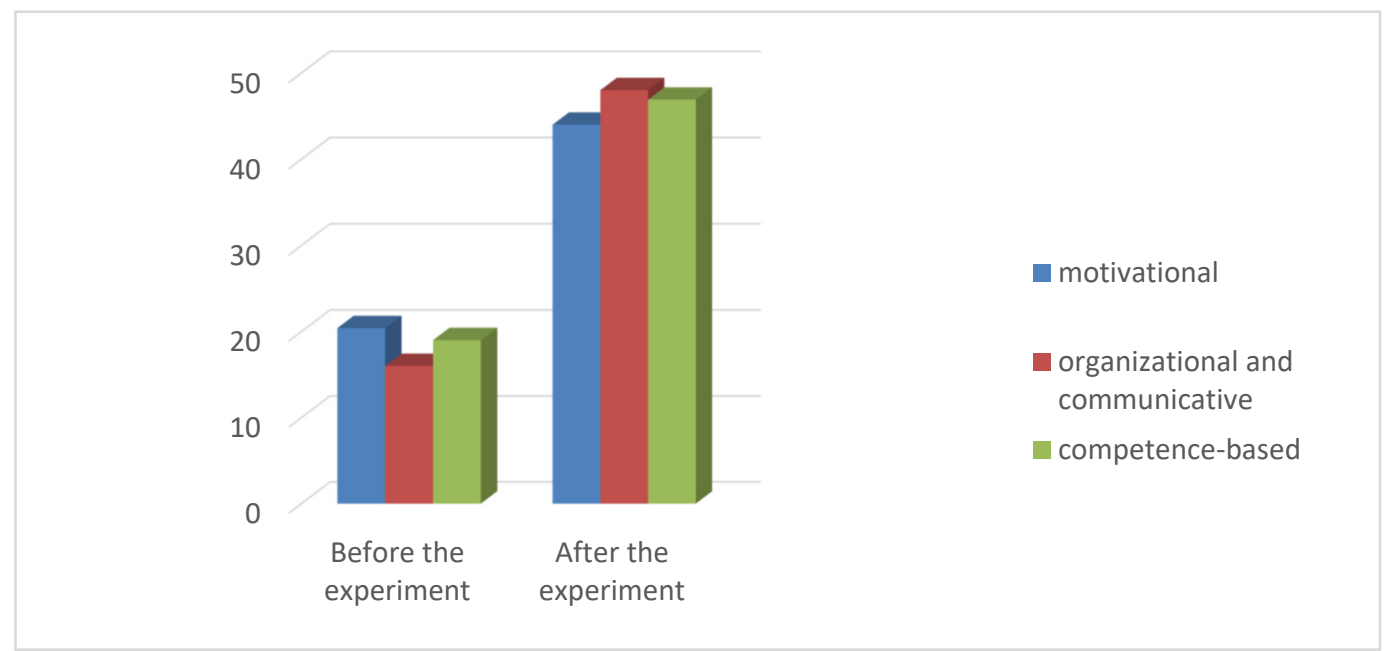

Figure 5. Levels of Students' Readiness to Form Innovative Media Education Styles before and after the Summative Experiment

The data obtained during the formative experiment showed that the students of the experimental groups had positive changes in the state of readiness to form innovative media education styles. While there were $8.4 \%$ of students with a high level of readiness during the summative experiment, after the experimental programme this indicator increased by $30.2 \%$ and amounted to $38.6 \%$ of the surveyed. Before the formative experiment, a sufficient level was found in $35.3 \%$ of the experimental group students, and after it - in $49.8 \%$ of students.

Besides, we can note that the number of students with a sufficient level of readiness both before and after the experiment in the control groups did not change: before the experiment $-36.2 \%$, after $-36.8 \%$. The analysis of the results of the experiment shows significant differences in the manifestation of a low level of readiness to educate the responsibility in senior preschoolers in students of experimental groups before and after the experimental work. Before the formative experiment, $56.3 \%$ of students had a low level, and these indicators decreased by $44.7 \%$ and amounted to $11.6 \%$ after the quiz to check the effectiveness of the experiment.

The results were determined on the basis of the analysis of the expert assessment of the manifestation of each of the criteria of readiness to form innovative media education styles by competent judges on a single scale: 5 - for a highly intensive manifestation, 4 - for quite intensive manifestation, 3 - for intensive manifestation; 2 - for a weak manifestation, 1 - for a very weak manifestation, 0 - for no manifestation of the feature (Figures 6,7 ). 


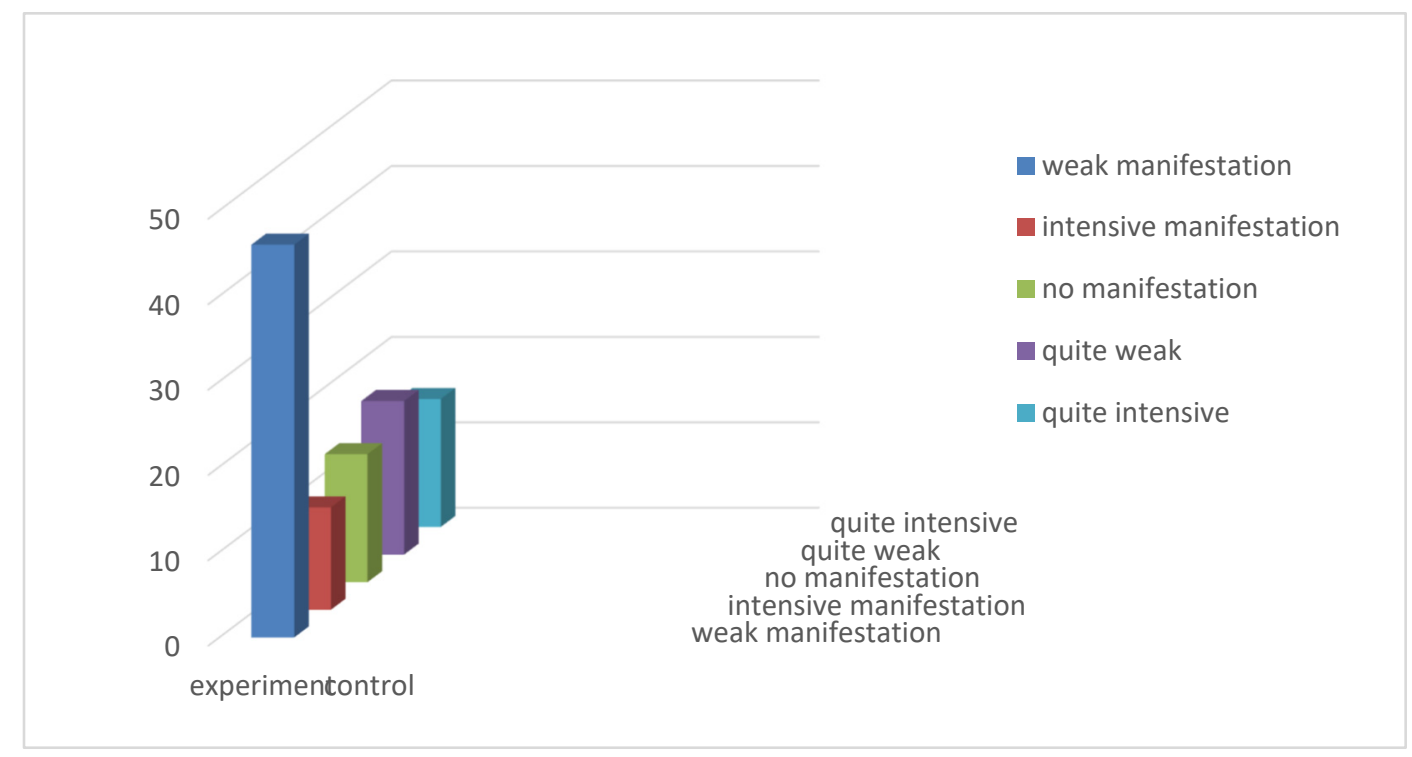

Figure 6. Manifestations of the Features before the Experiment

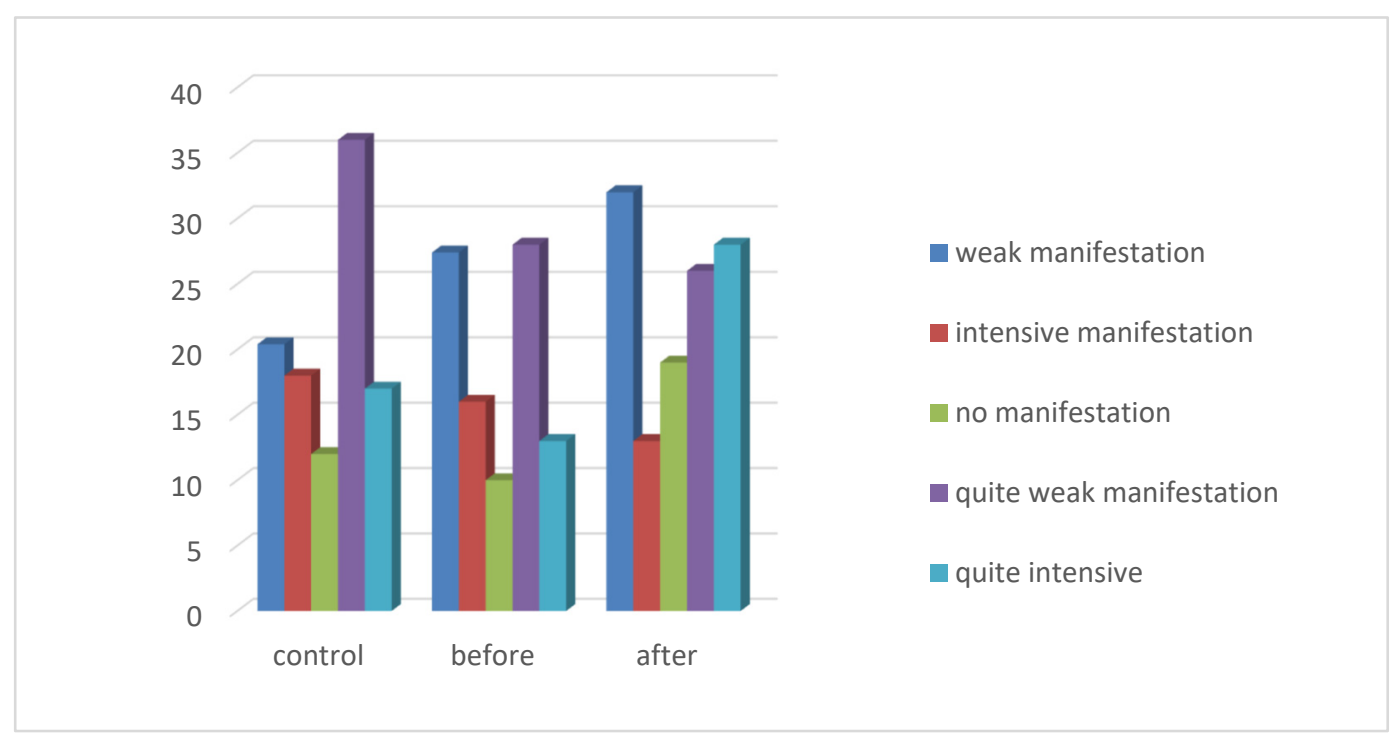

Figure 7. Manifestation of the Levels of Mastery of Innovative Styles after the Experiment

Some students had a low level: $42 \%$ in the experimental group and $46 \%$ in the control group.

According to the results of the final quiz, there were significant positive changes in all indicators in the experimental group students. The high level of readiness rose from about $38 \%$ to $48 \%, 26 \%$ of students had the medium level (compared to the initial 22\%), the low - 26\% (compared to the initial 40\%) (Figure 8). 


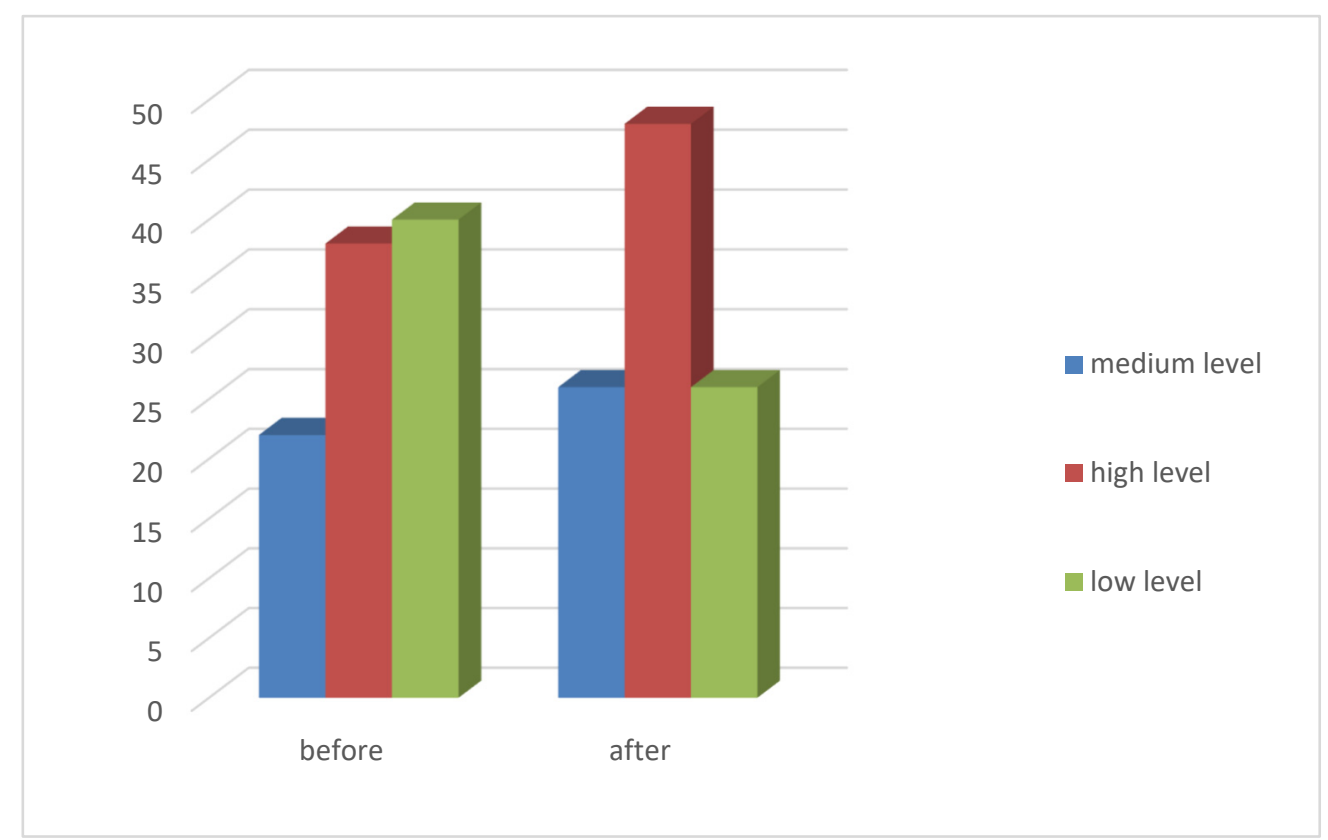

Figure 8. Manifestation of the Level of Professional Training of Future Specialists in the Control Experiment

On the other hand, the indicators in experimental groups before and after the specified period of study remained almost unchanged and amounted to: before $-10.6 \%$, after $-14.7 \%$. (Figure 9 ).

The generalized data are presented in Table 4, which shows the positive dynamics of the level of readiness in the experimental groups. So, the learning process contributes to increasing students' awareness of their role in the process of media education.

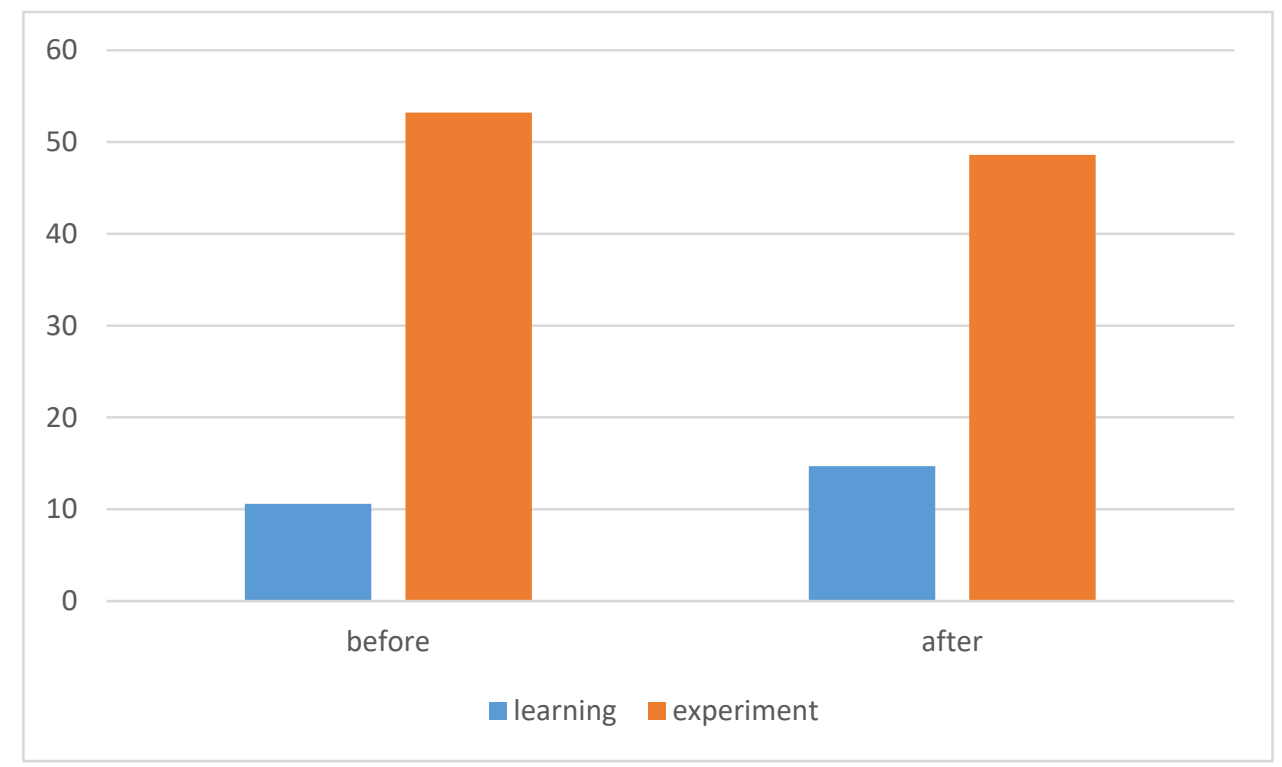

Figure 9. Indicators of Student Readiness 
Table 4. Indicators of Readiness Levels (before and after the formative experiment)

\begin{tabular}{|c|c|c|c|c|c|c|c|c|c|c|c|c|}
\hline \multirow[t]{3}{*}{ Levels } & \multicolumn{6}{|c|}{ Groups (\%) } & \multicolumn{6}{|c|}{ Groups (\%) } \\
\hline & \multicolumn{3}{|c|}{ Before the experiment } & \multicolumn{3}{|c|}{ After the experiment } & \multicolumn{3}{|c|}{ Before the experiment } & \multicolumn{3}{|c|}{ After the experiment } \\
\hline & $\mathrm{E}_{1}$ & $\mathrm{E}_{2}$ & $E_{3}$ & $E_{1}$ & $\mathrm{E}_{2}$ & $E_{3}$ & $\mathrm{C}_{1}$ & $\mathrm{C}_{2}$ & $\mathrm{C}_{3}$ & $\mathrm{C}_{1}$ & $\mathrm{C}_{2}$ & $\mathrm{C}_{3}$ \\
\hline High & 8.1 & 8.6 & 8.3 & 38.7 & 39.1 & 38.3 & 10.8 & 10.0 & 11.0 & 14.2 & 15.8 & 14.0 \\
\hline Sufficient & 35.8 & 35.2 & 35.0 & 50.9 & 48.5 & 50.0 & 37.5 & 37.9 & 34.0 & 36.7 & 37.1 & 36.5 \\
\hline Low & 56.1 & 56.2 & 56.7 & 10.7 & 12.4 & 11.7 & 51.7 & 52.1 & 55.0 & 49.1 & 47.1 & 49.5 \\
\hline
\end{tabular}

Therefore, the control stage of the experiment shows the main features of the introduction of innovative media education styles in the context of learning.

\section{Discussion}

The study identified that innovative styles are a manifestation of new approaches to media education. Media education is aimed at practical educational activities, use of media resources, critical analysis and representation of the main aspects of media sources. Troshani et al. (2018) believe that the perception of a media resource is possible only if there is a critical assessment, so that the media education will have results. We argue that media education is a manifestation of informatization and digitalization of social development. Under such conditions, media resources are a necessary factor in the evolution of modern society. Therefore, media education is formed in the process of digital technology development, and the acquisition of competencies is a natural process of socialization in the era of information and communication technologies.

The study revealed the transformation of digital technologies in the context of the organization of educational activities in higher education. The main context of the educational process and implementation of media educational approaches is determined. Bauman (2013) sees the problem in the media support of the educational activities.

The development of elements of the digital society is becoming a top priority, as the ability to apply digital technologies in the formation of an innovative post-industrial world depends on the holistic progress of mankind and determines the overall success of various institutions of social development (Oswald, 2018). This requirement of time forms new needs of mankind in the educational process, scientific, as well as social achievements, and also becomes decisive in the context of the formation of human value attitudes to innovative approaches to learning new categorical concepts.

Globalization and informatization of the 21 st century are the hallmarks of a new society with continuous progress and changing innovations in various fields, which requires new approaches to democratization, humanization and the need to acquire competencies in various fields of human activity (Allessie, Sobolewski \& Vaccari, 2019; Lazurenko, 2015; Vuckovic, 2019). The phenomenon of human innovation society is integrative methodological approaches to the networking of social interaction in the context of educational activities using information and communication technologies.

The latest technologies are transforming educational processes that rely on media education tools that change the perception of the educational process. Learning platforms are changing in the context of information and communication technologies, in particular, the virtual environment is becoming one of the important factors in changing the style of education, physical and social style is becoming an integration of online with traditional in-class education (Gumenyuk et al., 2021; Mashovets, 2017).

Social networks as a phenomenon of the information society in the context of the development of media education is a good prospect (Bessarab et al., 2021a). Development of scientific activity of students while studying in higher educational institutions forms innovative styles in the context of media education (Bessarab et al., 2021b).

Conceptual and innovative approaches of higher educational institutions to the model of training a successful professional during the Covid-19 pandemic are the basis for creating distance learning as one of the media education styles. Such perspectives are the basis for the introduction of innovative learning styles for students.

\section{Conclusions}

Media education in the age of informatization and ICTs is an important topic for research, because the formation of post-industrial society and digitalization of many spheres of public life requires a competent approach, therefore there is a need to use effective learning styles. 
Based on the analysis and experimental research, we determined the effectiveness of innovative styles of media education as a manifestation of information and communication technologies and prospects for successful social development. Innovative styles are a perspective in learning, as ICTs contribute to the formation of information, speech, mathematical and other types of competence. Media resources are widely distributed in cyberspace, social networks, so media education is relevant.

The study identified the essence of media education as a basis for the formation of innovative learning styles. We have formulated the main approaches to media education, in particular the use of media texts, media resources, video resources in the context of educational activities.

The main theoretical and methodological approaches to media education were analysed. Analysis of the concept of media education and information technology in the context of educational activities has become the basis for creating innovative styles. We have prioritized the use of hybrid styles that combine virtual and physical learning environments.

Effective innovative styles in the era of information and communication technologies as a basis for the integration of virtual and physical educational environment for students were experimentally studied. The experiment was the result of determining the levels of developed organizational and communication skills in students, determining the students' motivation to study, and their level of competence.

\section{References}

Abulalrub, I., \& Stensaker, B. (2018). How are universities responding to demands for improved learning environments? Journal of Further and Higher Education, 42(5), 721-732. https://doi.org/10.1080/0309877X.2017.1311991

Allessie, D., Sobolewski, M., \& Vaccari, L. (2019). Blockchain for digital government. Publications Office of the European Union. Retrieved from https://publications.jrc.ec.europa.eu/repository/handle/JRC115049

Bauman, Z. (2013). Liquid times: Living in an age of uncertainty. New York, NY: John Wiley \& Sons.

Bessarab, A., Mitchuk, O., Baranetska, A., Kodatska N., Kvasnytsia, O., \& Mykytiv, G. (2021a). Social networks as a phenomenon of the information society. Journal of Optimization in Industrial Engineering, 14(1), 35-42.

Bessarab, A., Sadivnychyi, V., Ilchenko, A., Ripka G., Shaposhnikova, V., \& Tainel, E. (2021b). Development of students' research activity during studying at higher education institutions. Estudios de Economia Aplicada, 39(5). https://doi.org/10.25115/eea.v39i5.4866

Bondar, I., Humenchuk, A., Horban, Y., Honchar, L., \& Koshelieva, O. (2021). Conceptual and innovative approaches of higher education institutions (HEIs) to the model of training a successful specialist formation during a COVID pandemic. Journal of Management Information and Decision Sciences, 24(3), 1-8.

Castells, M. (1996). The Information Age. Oxford: Blackwell.

Galán, J. G. (2016). Educational research in higher education: Methods and experiences. Aalborg: River Publishers.

Gardner, H. (1983). Frames of mind: The theory of multiple intelligences. New York, NY: Basic Books.

Giddens, A. (1991). Modernity and self-identity. Self and society in the late modern age. Cambridge: Polity Press.

Gray, P. (2008). A brief history of education. To understand schools, we must view them in historical perspective. Psychology today. Retrieved from https://www.psychologytoday.com/us/blog/freedom-learn/200808/brief-history-education

Greenhow, C., Sonnevend, J., \& Agur, C. (2016). Education and social media: Toward a digital future. Cambridge, MA: MIT Press.

Gumenyuk, T., Kushnarov, V., Bondar, I., Haludzina-Horobets, V., \& Horban, Y. (2021). Transformation of professional training of students in the context of education modernization. Estudios de Economia Aplicada, 39(5). https://doi.org/10.25115/eea.v39i5.4779

Gygli, S., Haelg, F., Potrafke, N., \& Sturm, J. E. (2019). The KOF globalisation index-revisited. The Review of International Organizations, 14, 543-574.

Katz, J. (2013). The three block model of universal design for learning (UDL): Engaging students in inclusive education. Canadian Journal of Education, 36(1), 153-194. 
Lazurenko, O. O. (2015). The development concepts 'emotional intelligence' in psychology. Scientific Review, 1(11), 1-10.

Loreman, T., McGhie-Richmond, D., Kolopayvea, A., Tarenchenko, O., Mazin, D., \& Crocker, C. (2016). A Canada-Ukraine collaborative initiative for inclusive education in Ukraine: Participant perspectives. School Effectiveness and School Improvement, 27(1), 24-44.

Mashovets, M. A. (2017). Carrying lidership as preschool teacher's professional competence. Young Scientist, $3.2(43.2), 29-35$.

Milman, V. E. (2017). Diagnostics of motivation structure of the personalities. Retrieved from http://www.miu.by/kaf_new/mpp/017.pdf

Negroponte, N., Harrington, R., McKay, S. R., \& Christian, W. (1997). Being Digital. Computers in Physics, 11(3), 261-270. https://doi.org/10.1063/1.4822554

Nelson, K., Courier, M., \& Joseph, G. W. (2011). An investigation of digital literacy needs of students. Journal of Information Systems Education, 22(2), 95-109.

Noonan, K. (2017). Cyber security for digital government leaders- A guide for government senior executives responsible for leading digital initiatives. CISCO. Retrieved from https://www.cisco.com/c/dam/global/en_sg/assets/pdfs/cisco_whitepaper_govt_cyber_security_digital_2017050 4.pdf

Nychkalo, N. G. (2008). Transformation of vocational education in Ukraine. Kyiv: Pedadgogichna dumka.

Oswald, M. (2018). Algorithm-Assisted Decision-Making in the Public Sector: Framing the Issues using Administrative Law Rules Governing Discretionary Power. The Royal Society Publishing. https://doi.org/10.1098/rsta.2017.0359

Synyavsky, V., \& Fedoryshyn, A. (2016). Methodology "Assessment of communicative and organizational abilities of the individual" KOS-1. Retrieved from https://studfile.net/preview/5258514/page:106/

Troshani, I., Janssen, M., Lymer, A., \& Parker, L. D. (2018). Digital transformation of business-togovernment reporting: An institutional work perspective. International Journal of Accounting Information Systems, 31, 17-36. https://doi.org/10.1016/j.accinf.2018.09.002

Vdovych, S. M., \& Palka, O. V. (2013). Modern educational technologies of language training of future service professionals. Kyiv: Pedadgogichna dumka.

Vuckovic, T. (2019). The overall goal of education and general purpose. International Journal for Empirical Education and Research, 3(20), 53-66.

\section{Appendix A.}

\section{Questionnaire "Media resources - a source of knowledge and skills"}

Rate your answers from 1 to 3, where 1 - yes, 2 - I do not know, 3 - no.

1. Do you use media resources in preparation for the lesson?

2. Do you use media news in preparation for the lesson?

3. Do you conduct classes in Zoom?

4. Are you impressed by online classes?

5. Do you learn better from media resources?

6. Do you use journalistic investigations in preparation for classes?

7. Do you use social networks in preparation for the lesson?

\section{Copyrights}

Copyright for this article is retained by the author(s), with first publication rights granted to the journal.

This is an open-access article distributed under the terms and conditions of the Creative Commons Attribution license (http://creativecommons.org/licenses/by/4.0/). 